DOI 10.33234/ssr.13.3

\title{
The Performativity of the Archive from a Semiotic Perspective
}

\author{
By Martin Acebal, Claudio Guerri, Cristina Voto
}

\begin{abstract}
The paper proposes a Peircean semiotics approach to the Archives Studies based on the notion of performativity. In this context, the study of discourses shifts from the representational verification to their effectiveness; the question is no longer about what they represent, but about what discourses are capable of producing in a time and a community. The objective of the paper is to challenge the cultural practice of archiving with these notions. To do this, a semiotic methodology is used to allow the investigation of the ways in which the archives make sense, as well as the aspects that are involved in that production of meaning. Three major interrelated fields of research will thus be defined: the archive as construction of a memory; the archive as the storage and constitution of objects and documents; the archive as the systematization of the archive material.
\end{abstract}

Keywords semiotics, archive, performativity, cultural semiotics, methodology. 


\section{Introduction}

This article arises in response to an effective demand which emerged during the teaching of "Semiotics" at the Universidad Nacional de Tres de Febrero -UNTREF-, as part of the Electronic Arts Degree. The subject "Semiotics" develops a methodology for the study of the dimensions involved in the production of meaning carried out by contemporary artistic practices, in this case, especially those related to Electronic Arts. During the semester, students must analyze artworks they are developing — or have already produced — for other subjects. What we have identified is the increasing use of what is generally called archival materials by students. The term is used in a slightly imprecise way and, at the same time, collects a miscellany of diverse elements: from sound records ordered and cataloged by recognized institutions, to found footage, images or audiovisuals belonging to the private sphere and recently found or exhumed, etcetera.

As it is a "material", an input or a raw material for the production of artworks, we consider that it is necessary to study the practice of archiving from a semiotic perspective. We are interested in understanding the potential of these materials to produce and transform meanings. Within the Research Project entitled "Semiotics of performativity: epistemological lens, event and performative effect", we have elaborated some semiotic reflections about the complex theme of the "archive", its emergence and its uses. Our methodological framework is the Semiotic Nonagon (Guerri, 1984 [1988]: 353-354; 2003: 157-174; 2014 [2016]: 3-40), an operative model for qualitative research based on the semiotic postulates of Charles Sanders Peirce.

\section{State of the Art on Archive Studies}

Since the last decade of the 20th century, production in relation to Archive Studies has increased exponentially. The result is an endless amount of bibliography production if we do not have some tools to select and organize relevant studies for specific research. To carry out this selection and organization, this article proposes a Peircean reading of Archive Studies in a performative 
The Performativity of the Archive from a Semiotic Perspective

key. In this way, we can group these studies into three large areas: institutional archive policies; the materiality of the archive; and the artistic-poetic reworkings of the archive. Louis Althusser (1965 [1973]: 132-159) recognizes, within Social Practice, three classes of practices: 1. theoretical or ideological practice; 2. economic practice; and 3. political practice. Each of these social practices can be related to the Peircean categories of Firstness, Secondness and Thirdness, respectively. In the following sections, we organize the state of the art according to these three kinds of practices, but inverting the sequence -for explanatory purposes- by following the Peircean statement of "Symbols grow" (CP 2.302, 1895): institutional archive policies_political practice-; the materiality of the archive-economic practice-; and the artistic-poetic reworkings of the archive-theoretical-ideological practice.

\subsection{Institutional archive policies}

This area is related to the archives' political strategies. It brings together a series of works that have focused on the epistemological, democratizing and visualizing possibilities of the archive. In relation to the first aspect - the epistemological possibilities - , archives have usually been understood as places of "selection, classification and storage of textual, visual and sound objects of knowledge" (Göbel and Müller, 2017: 19). From this perspective, Foster (2004: 4) points out that "[the archive] seeks to physically present historical information, often lost or displaced". Both Stoler (2010) and Göbel and Müller (2017) question this somewhat idealized image and point out the colonizing nature of archives in the central nodes of Europe and the United States, since they allow their researchers "the possibility to compare diversity from one single place" (Göbel and Müller, 2017: 20).

This last proposal introduces us to the second aspect that we have already mentioned: democratization. For Giunta, (2010: 23) archive policies in Latin America:

"are based on a key word: democratization. The term has the power to tie wills immediately, almost as if it were a popular front or a letter to gather signatures in favor of a just cause. (...) But declassifying archives does not necessarily imply declassifying knowledge policies." 
For Taylor (2019: 39), the fetishization of the archive is capable of rendering its economic and political interests invisible:

"like a fetish, [the archive] spreads over various contradictory and irreconcilable power mechanisms. However, one must understand the power and control behind the archive to assess the political and economic implications of what is kept and what is forgotten." (our emphasis)

Finally, archives have been studied, especially in Latin America, for their political capacity to denounce and make visible repressive practices, censorship and exploitation (Markarian, 2016; Ferraz Fernandes, 2007; Da Silva Catela, 2002), which transforms their status from that of "mere deposits" into that of "places in dispute" (Balé, 2018; Tello, 2015).

\subsection{The materiality of the archive}

This area concerns the economical strategies of archives. It is constituted by the problems arising from their materialization. Every archive consists of a certain accumulation of materials and requires a space where these materials are protected. In relation to this point, some studies emphasize the way in which archives are able to give value to materials that have usually been considered minor (Foster, 2004; Giunta, 2010). Other authors have studied the way in which certain documents function, in museums, as substitutes for works that can no longer be recreated (Groys, 2008).

But the subject with the greatest interest today is the "digitization" or "digital transformation" of archives. For some authors, digitization makes institutional and disciplinary spaces more permeable (Hui, 2016) and allows the creation of "digital ecosystems of knowledge". Göbel and Müller (2017), on the other hand, point out that digitization implies a loss of the sensory and haptic experiences that arise from interaction with the object. Digitization, for these authors, can also generate new hierarchies or the loss of visibility of nondigital, non-digitized or non-digitizable objects. 
The Performativity of the Archive from a Semiotic Perspective

These considerations on the materiality of the archive also include its modes of circulation. In one sense, digitization recovers the ideal of democratization and free access. In another sense, it questions the authority of institutions to legitimize and manage these materialities. From this perspective, Göbel and Müller (2017: 23) suggest the emptying of archives, what they call "digital extractivism".

\section{3 The artistic-poetic reworkings of the archive}

This area is related to the theoretical strategies of archives, and is the most frequent aspect of the archive found in discussions about contemporary art and Latin American art in particular. Guasch (2011) places the "archive" as the third paradigm within the art studies that started with the first avant-gardes. For this author, the perspective of the archive abandons the idea of the artistic object and gives creation an "aesthetic of the legal-administrative organization".

For Osthoff (2009), the archive is no longer a material for the work of art; rather, it itself becomes a work of art. Barriendos (2012) calls this the "archival turn" of contemporary art. Rolnik (2010) investigates the different poetics that artistic practices of the archive have generated, from the historical perspective of Benjamin. For this author, as for Tello (2015), art must "stir, activate, revulse" the archive to find in it marks of a future, and not just the testimony of the past.

\section{The descriptive fallacy of languages}

Based on what has been stated above, we propose an approach to the phenomenon of the archive based on the notion of "performativity". The term is understood, at least in a first instance, as characterized by John Austin (1962) and his disciple John Searle (1969) in their Theory of Speech Acts. What Austin (1962: 42) proposes in his lectures is a review of what he calls the "descriptive fallacy of language". In accordance with an informational, representational approach to language, all verbal statements - and we can also extend the affirmation to other languagesare conceived, in a first approximation, as "verifications", representations, registers of a reality or of an extra-discursive experience. The analysis of these statements would consist of a contrast 
with that reality, either to show their truth or falsehood - in a more modern approach-or to show their partial, arbitrary and biased nature - in a more contemporary approach.

In opposition, the notion of performativity postulates that discourses are not limited to verifying or describing a reality, but actually produce or transform it. In this way, Austin argues that certain statements, in certain circumstances, do not "register" the name of an object or a person, but rather "name" it - for example, at baptism-; they do not simply describe a social relationship between two subjects, but construct it by the very act of speech that involves them-for example, when a marriage takes place. In this perspective, the study of statements or discourses moves from "representational verification" to "the conditions of effectiveness" of those statements. That is, what conditions are necessary for a discourse to operate, and act on reality and experience?

\section{The fallacy of the archive}

Following on from the previous section, we can infer that an approach to the archive from the perspective of performativity requires investigating the informational or representational "fallacy" of the archive. For this we can recover the first formulations made by Guasch (2011: 13) in her text Arte y archivos, 1920-2010. Genealogías, tipologías y discontinuidades, where the author proposes a first characterization of the archive "as a mnemonic supplement that preserves memory and rescues from oblivion, amnesia, destruction, annihilation, to the point of becoming a true memorandum". For this author, the archive is a "mnemonic supplement" because it articulates the mnéme - the living memory resulting from internal experience-with the hypomnema - the act of remembering. The act of remembering would have its limitationsmemory capacity, survival of the person who remembers-, so it would require a supplement. But this supplement is also "mnemonic" because it proposes a technique for memory organization. This allows Guasch (2011) to differentiate "storing" or "collecting" from "archiving".

Storing "consists of 'assigning' a place or depositing something - a thing, an object, an image -in a specific place" (Guasch 2011: 10; emphasis in the text); on the other hand, archiving implies a "grouping", but it [also] demands to unify, identify, classify, its way of 
proceeding is not amorphous or indeterminate but is born with the purpose of coordinating a “corpus" within a system or a synchrony of elements previously selected” (Guasch 2011: 10).

The key to beginning to clarify the fallacy of the archive can be traced at the end of the last quote: "previously selected elements". The archive, from this point of view, maintains a subsidiary relationship with that "prior selection", just as the descriptive-constative conception of language maintains a subsidiary relationship between a statement and the reality or experience it represents, although such a representation is made in a more or less precise way, capturing certain aspects and discarding others. Briefly, in this approach, the archive is made up of three elements:

- an organization or classification;

- a memory resulting from experience - or a substitute: image, object, verbal speech, etcetera-; and

- a criterion of selection.

These three elements are linked to each other to achieve the objective of "preserving memory and rescuing from oblivion". Certain experiences that are considered memorable are organized in a particular way to be remembered in a certain way. For this reason, Guasch affirms that the "paradigm of the archive" makes a passage from the object—artistic, auratic — to the support of information. The object becomes a support for information insofar as it constitutes a support for a memory resulting from "previously selected" experiences.

What is the fallacy of the archive? To answer this question, it is necessary to investigate the subsidiary nature of the connection that arises between the archive and organized memorable memories. This is precisely the approach that allows the notion of performativity. Within the Austinian framework, we could say that the archive does not preserve a memory, but constitutes it at the moment in which it is safeguarded; or rather, that it makes a memory memorable in the very act of displaying a mnemonic to remember it. This is what Derrida (1995: 17) refers to when he says: 
the archive, as printing, writing, prosthesis, or hypomnesic technique in general is not only the place for stocking and for conserving an archivable content of the past which would exist in any case, such as, without the archive, one still believes it was or will have been. No, the technical structure of the archiving archive also determines the structure of the archivable content even in its very coming into existence and in its relationship to the future. The archivization produces as much as it records the event. [first emphasis in original, second ours].

This first identification of the fallacy of the archive - "the archivization produces as much as it records the event"- needs or can be complemented by the contributions of the triadic and logic-based semiotics of Charles Sanders Peirce and the methodology of the Semiotic Nonagon. The first of the projections of this fallacy that Peircean semiotics affords us is to identify which are the aspects involved in the production of meaning carried out by the archive. This means thinking about the archive as a sign.

We have already said that the archive is constituted by three aspects. Each of these elements refers to the aspects that constitute one of the definitions of the sign (CP 2,228, 1897) in Peirce (Table 1).

\begin{tabular}{lll}
\hline An archive is constituted by & A sign is something & T e r m i n o l o g i c a 1 \\
(Guasch 2011) & (Peirce) & reformulation for the SN \\
\hline - an organization [that & - in some respect... & - Ground / Form \\
coordinates] & & \\
- memory/objets memorables & - for something & - Object / Existence \\
[according to] & & \\
- a selection criterion & & - to somebody \\
\hline
\end{tabular}


Table 1: Relationships of the constituent elements of the archive for Guasch (2011) with the aspects of Pierce's triadic sign (CP 2.228, 1897). The last column introduces the terminological reformulation proposed by Guerri (1988, 2003; 2014 [2016]).

The archive, as a sign, is something which stands to somebody - a certain criterion that postulates a "selective memory" of events_-, for something - a concrete memory forged in an experience, or an object, an image, a document, etc. that operates as a substitute-, in some respect or capacity — according to a certain organization and classification.

In this semiotic approach, the memory or the memorable object-the Existent, the "archive material" - only makes sense when it takes a Form that organizes and systematizes it, removes it from pure "amorphous storage"; and when the object takes a Value-a social and artistic interpretant — that makes it a substitute or testimony of a past event. The memory or the object, then, ceases to be "the individual fact that insists on being here regardless of any [quality and] reason" (CP 1.434), to enter as Existent in the semiotic process.

This first approach allows us to identify areas of investigation of the archive with specific and articulated problems at the same time. On the other hand, it permits us to expand the study of the performativity of the archive and recognize the dimensions involved in its effectiveness. An effectiveness capable - according to Derrida — of producing the event that it records.

\section{The performativities of the archive}

In a previous work (Acebal et al., 2014) we showed that the traditional approach to performativity - from the Philosophy of Language - placed all the emphasis on the role that conventions played in the effectiveness of a discourse. The attention to the fulfillment of certain steps, in the conditions of legitimacy of the producers, among other elements, built an image of performativity focused only on those aspects that Peircean semiotics calls symbolic. The objective of that article was to show how the analysis of the size and location of the images allowed us to recognize specific effectiveness of the images that was not limited to their symbolic and valuative aspects. We stated that the performativity of the images also involved their formal-iconic and material-indexical features, producing what we called contingent 
performativity. As the Gestalt demonstrates, the formal qualities of images can operate on other images, altering the perception of size, continuity, etcetera. The same can be said about the material characteristics and the location of the images: these features are also capable of affecting and involving bodies and transforming spaces.

In this way, the triadic approach to performativity broadens the original postulates and allows us to speak of a symbolic performativity, an indexical performativity and an iconic performativity, depending on whether the effectiveness is attributed-predominantly-to its valuative, material or formal aspects, respectively.

Within the framework of this article, the identification of three particular dimensions of effectiveness in the study of performativity requires recovering the three aspects operating in the archive. We said that the archive was constituted by "a certain organization and systematization; a group of objects, documents, images, etc. that operated as substitutes for the event; and a selection criterion, which guides and gives the reasons which make the event memorable".

The hypothesis that we want to propose in this work affirms that each of these constitutive aspects has its specific effectiveness in the construction of the performativity of the archive. At the same time, it can be argued that, in each conjuncture or curatorial proposal, some of these elements can acquire a greater role and make their effectiveness dominate over that of the others.

\subsection{The symbolic performativity of the archive}

The symbolic performativity of the archive investigates the capacity of archives, institutions, groups, and states to build a memory, to inscribe the present in struggles, in conquests, but also in traumas and losses. Symbolic performativity is what makes certain events memorable; it is able to highlight certain episodes that are considered relevant to the present times from the undifferentiated continuum of history. Here we can find those studies, especially in Latin America, that show the political capacity of the archive to denounce and make visible repressive practices, censorship and exploitation (Da Silva Catela, 2002; Ferraz Fernandes, 2007; Markarian, 2016). It is from these studies that the archives are no longer seen as "mere deposits", but understood as "places in dispute" (Balé, 2018; Tello, 2015). At this point, the archive exhibits 
The Performativity of the Archive from a Semiotic Perspective

what Derrida (1996: 77) calls "archontic power": the power that magistrates possessed to safeguard documents and, at the same time, to interpret them.

\subsection{The indexical performativity of the archive}

The indexical performativity of the archive reflects on the capacity of objects and documents to constitute an event, and not only to materialize a memory established in a different instance - the symbolic one. This is relevant for those cases in which, as Osthoff (2009) argues, the archive ceases to be mere material for a work of art, and transforms itself into a work of art. In a curatorial proposal that began in May 2018 — and ended the same month in 2019-the Provincial Museum "Rosa Galisteo de Rodríguez" in the city of Santa Fe, Argentina, used all its exhibition rooms to display the 2700 artworks that constitute the museum's heritage. The works were arranged, almost stacked, without any acknowledgment of traditional grouping criteria or the criteria proposed by a room text or a catalog. The exhibition was called "Taken Museum"-"Museo tomado", in Spanish-and the exhibited artworks did not remain for long, because they were replaced, week after week, by new heritage works, whose storage was also part of the exhibition. At the same time, visitors could see the process of restoration of the works, which was taking place in nearby rooms. The exhibition space tried to contain these restoration activities and the excess of the archived heritage.

In cases like these, it is the very materiality and excess of the archive that prevails over the selection criteria—symbolic - and the organization criteria—iconic. The documents, objects and artworks involved in these proposals do not admit a conventional understanding of the archive. They are not conceived or experienced as material instantiations of a memory, as "symbolized singularities". Materials become operative, capable themselves of forging an event or the experience of that event. These materials do not necessarily require a discursive scaffolding that inscribes them in a narrative or a politics of memory.

Archives that seek to recreate the experience of the event can also be considered within this group. These are archives that offer the visitor a much more somatic than cognitive relationship with the historical event being remembered. This is what happens at the Jewish 
The Performativity of the Archive from a Semiotic Perspective

Museum in Berlin and its Holocaust Tower; or the high granite walls next to the entrance ramp in the Parque de la Memoria de Buenos Aires. Issues related to the domiciliation of the files and their digitization are also grouped here. This last phenomenon-digitization-becomes relevant for the study of indexical performativity insofar as it implies, as Göbel and Müller (2017) point out, a loss of the sensory and haptic experiences that arise from the interaction with archival materials.

\subsection{The iconic performativity of the archive}

The iconic performativity of the archive explores the effectiveness of the archive to project onto the materials a form that functions as a selection criterion for future objects, documents, etc. They will be "archive material" insofar as they correspond to the features organized and systematized by the archive. Buchloh (1999: 32) affirms that in contemporary art we find an "aesthetic of legal-administrative organization" of the archive. What is of interest here is the way in which this aesthetic operates as a device for cataloging, but also as a device for the intellection of archive material. The performative character is recognized when the organizational criteria no longer offer a technique-mnemotechnies - to classify and order what is available, and become agents of selection of what is considered classifiable, that is, iconically archivable. On the other hand, a part of this iconic performativity of the archive would consist in producing its own indivisible remainder, a kind of asylum ignorantiae where unclassifiable materials can be located.

But the iconic character of this performativity does not only refer to the formaltheoretical - characteristics of the archive. The iconic performativity of the archive also alludes to visual representations with mnemonic purposes, such as the so-called "memory palace" referred to by Saint Augustine in his Confessions (Book X, 8-26) or the more contemporary developments of data visualization (Dondero, 2016).

\section{Conclusion}

In this article we aimed to demonstrate that the archive can be understood as an epistemological lens - another of the meanings attributed by Diana Taylor (Taylor y Fuentes, 2011) to the notion 
of "performance". This epistemological lens operates on phenomena, discourses and documents to recognize in them their "archival" character. The archive recognizes in phenomena, discourses and documents the capacity to construct a memory, recreate an event and organize and classify memories.

The study on the performativity of the archive invites us to think about its own hypertrophy. An example is the phenomenon that leads to the conservation of objects and documents without being able to specify exactly what the event is that is being remembered, what Foster (2004) described as the "archiving impulse" and then Suely Rolnik (2010) called "archiving fury". The performativity of the archive also denounces the fossilization of the classification criteria that render invisible those elements that do not respond to the features stipulated for cataloging and systematization.

The students" "archive materials" can now be analyzed from these three different areas of performativity to inquire into their formal, material and value conditions of constitution and also their specific effectiveness, in order to be able to operate on them in the production process of a work of art.

\section{Bibliography}

ACEBAL, M., BOHÓRQUEZ NATES, M., GUERRI, C. y VOTO, C. 2014. "La manumisión de las imágenes", in Lexia 17-18, 71-90. Turin: Aracne.

ALTHUSSER, L. (1965). “6. Sobre la dialéctica materialista (de la desigualdad de los orígenes)", in La revolución teórica de Marx, pp. 132-159, Buenos Aires: Siglo XXI, 1971.

AUSTIN, J. L. 1962. Cómo hacer cosas con palabras, Buenos Aires, Paidós, 2008.

BALÉ, C. 2018. "Usos del archivo y políticas de la memoria: un análisis del proceso de 'apertura' de los archivos militares en Argentina (2003-2015)", Nuevo Mundo Mundos Nuevos. http://journals.openedition.org/nuevomundo/73860 (visited March 2020)

BARRIENDOS, J. 2012. "Reterritorializando los sesentas. Archivos, documentos y posestructuralismo en el museo de arte", in Castillo, A. and C. Gómez-Moya (eds). Arte, archivo y tecnología, Santiago: Univ. Finis Terrae. 
BUCHLOH, B. 1999. “Atlas/Archive”, Coles, A. (ed.) The Optic of Walter Benjamin. Londres: Black Dog Publishing.

DA SILVA CATELA, L. 2002. "El mundo de los archivos", Da Silva Catela, L. and Jelin, E. (eds.). Los archivos de la represión: documentos, memoria y verdad, 195-219.

DERRIDA, J. 1996. Archive fever: A freudian impression. Chicago: University of Chicago Press. DONDERO, M. G. 2016. "Using images to analyze images. Semiotics meets Cultural Analytics", Reyes-García, E., Chatel-Innocenti, P. y Zreik, K. (eds.). Archiving and Questioning Immateriality: Proceedings of the 5th Computer Art Congress, Paris: Europia.

FERRAZ FERNANDES, J. D. 2007. “Os desafios da preservação da memória da ditadura no Brasil”, Abreu, R., De Souza Chagas, M. and Sepúlveda, M. (eds.). Museus, coleções e patrimônios: narrativas polifônicas, v. 1, pp. 48-67. Río de Janeiro: Garamond Universitária.

FOSTER, H. 2004. “An Archival Impulse”, Oktober 110, 2004, pp. 3-22.

GÖBEL, B. y MÜLLER, C. 2017. “Archivos en movimiento: ¿Qué significa la transformación digital para la internacionalización de los archivos?”. Göbel, B. and Chicote, G. (eds.). Transiciones inciertas: Archivos, conocimiento y transformación digital en América Latina. La Plata: UNLP; Berlin: Ibero-Amerikanischen Instituts.

GIUNTA, A. 2010. “Archivos. Políticas del conocimiento en el arte de América Latina”, Errata. Revista de Artes Visuales 1, pp. 20-37.

GROYS, B. (2008). "Art in the Age of Biopolitics: From Artwork to Art Documentation", Art Power. Cambridge Mass: The MIT Press, pp. 53-65.

GUASCH, A. M. 2011. Arte y archivo, 1920-2010. Genealogías, tipologías y discontinuidades. Madrid: Akal.

GUERRI, C. F. 1988. "Semiotic characteristics of the architectural design based on the model by Charles S. Peirce", HERZFELD, M. and L. MELAZZO (eds.). Semiotic Theory and Practice, Proceedings of the III Congress of the IASS-AIS, Palermo 1984, pp. 347-356. Berlin: Mouton de Gruyter. 
The Performativity of the Archive from a Semiotic Perspective

GUERRI, C. F. 2003. El nonágono semiótico: un icono diagramático y tres niveles de iconicidad. deSignis 4, julio 2003, 157-174. Buenos Aires: Gedisa-FELS.

GUERRI et al. 2014. Nonágono Semiótico. Un modelo operativo para la investigación cualitativa. Buenos Aires: EUDEBA and Ediciones UNL. 2nd. edition 2016.

HUI, Y. 2016. On the Existence of Digital Objects, University of Minnesota Press.

MARKARIAN, V. 2016. "Los documentos del pasado reciente como materiales de archivo. Reflexiones desde el caso uruguayo", in Contemporánea. Historia y problemas del siglo $X X$, Vol. 7, pp. 178-191.

OSTHOFF, S. 2009. Performing the Archive: The Transformation of the Archive in Contemporary Art from Repository of Documents to Art Medium. Nueva York: Atropos Press.

PEIRCE, C. S. 1931-58. Collected Papers of Charles Sanders Peirce, Vols. 1-6, Hartshorne, C. and P. Weiss (eds.). Vols. 7-8, Burks, A. W. (ed.). Cambridge (US): Harvard University Press.

ROLNIK, S. 2010. "Furor de Archive", Errata. Revista de Artes Visuales, 1, pp. 38-53.

SEARLE, J. 1969. Actos de habla: ensayo de filosofía del lenguaje, Barcelona: Planeta, 1994.

STOLER, A. L. 2010. Along the Archival Grain. Epistemic Anxieties and Colonial Common Sense, Princeton y Oxford: Princeton University Press.

TAYLOR, D. (2019). "Archivos digitales", en Carrillo Herrerías. S. and S. Henaro (eds.) Archivos fuera de lugar. Desbordes discursivos, expositivos y autorales del documento, México: Museo Universitario de Arte Contemporáneo.

TAYLOR, D. y FUENTES, M. 2011. Estudios avanzados de performance. México: Fondo de Cultura Económica.

TELLO, A. M. 2015. “El arte y la subversión del archivo”, Aisthesis, 58, pp. 125-143.

\section{Martín Acebal}

Universidad Nacional de Tres de Febrero;

Universidad Nacional del Litoral;

Universidad Nacional Guillermo Brown, Argentina. 


\section{martinacebal@gmail.com}

Martín Acebal is a professor in 'Semiotics' at the National University of Tres de Febrero (UNTREF, Argentina), a professor in 'Theory of Argumentation' at the National University of Litoral (UNL, Argentina), and a member of the Area of Discursive Competences at the National University Guillermo Brown (Buenos Aires, Argentina). He obtained his Ph.D. in Linguistics at the University of Buenos Aires, with a thesis about discursive strategies in Catholic homilies. His academic research has focused on Discourse Analysis, Verbal and Visual Semiotics, and Rhetorical Studies. He has been a visiting professor at the Autonomous University of Madrid (UAM, Spain) and at the Autonomous University of the State of Mexico (UAEM). He has made a research stay at the Ibero-Amerikanisches Institut (IAI, Germany). He is a member of the Board of Directors of the Argentine Association of Rhetoric (AAR) and has worked in the organization of its last congress in 2019. He has presented many works at national and international conferences on Semiotics, Linguistics and Rhetoric. He has published many articles in several specialized magazines. He has been co-editor of the book Nonágono Semiótico. Un modelo operativo para la investigación cualitativa (Buenos Aires: EUDEBA, 2014 and 2016).

\section{Claudio Guerri}

Universidad de Buenos Aires;

Universidad Nacional de Tres de Febrero, Argentina.

claudioguerri@gmail.com

Claudio Guerri was born in Rome, Italy, 1947. He is an Architect, Consultant Professor and Doctor at the Facultad de Arquitectura, Diseño y Urbanismo of the Universidad de Buenos Aires, UBA, where he teaches Semiotics at the Doctorate. There, he also directs the Research Program: Semiotics of Space-Design Theory. He teaches Semiotics also at the Universidad Nacional del Litoral, UNL, and the Universidad Nacional de Tres de Febrero, UNTREF. He has lectured and taught graduate seminars in many countries in North and South America, Europe, Middle East and China. His area of interest is Morphology, Graphics Languages and the development of methodologies and models of applied semiotics for qualitative research. He is or was a member of the Executive Committee of several international scientific societies as IASS-AIS; IASSp; FELS; ISIS-Symmetry, national societies as SEMA, AAS, and editorial staff as in deSignis, ARTINF, Cuadernos de la Forma. He has written articles on art, architecture, design and semiotics in Spanish, English, Italian German and French; and has published Lenguaje Gráfico TDE. Más allá de la Perspectiva (Buenos Aires: EUDEBA, 2012) and Nonágono Semiótico. Un modelo operativo para la investigación cualitativa (Buenos Aires: EUDEBA, 2014 and 2016).

\section{Cristina Voto}

Universidad Nacional de Tres de Febrero, Argentina;

Università di Torino, Italia.

crivoto@gmail.com

Cristina Voto is a postdoctoral researcher at the University of Turin (FACETS _ ERC Project), a professor in 'Semiotics' at the National University of Tres de Febrero (UNTREF, Argentina), an 
adjunct professor in 'Visual Communication' at the University of Turin (Unito, Italy), and a curator of the Biennial of the Moving Image (BIM, Buenos Aires). Her academic research has focused on visual semiotics, design studies, digital arts, futures studies, and gender \& queer studies. She obtained her Ph.D. in Design at the University of Buenos Aires (UBA, Argentina) with a thesis that explores the epistemic entanglement between image design and biopolitics. She has been a professor in 'Theory of Architecture in Global South' at the University of La Matanza (UNLaM, Argentina) and a lecturer in 'Audiovisual Design' at the University of Buenos Aires (UBA, Argentina). She has been a visiting professor at the Jorge Tadeo Lozano University of Bogotá (UTadeo, Colombia), and at the Autonomous University of Madrid (UAM, Spain). She has also been a visiting researcher at the Nacional University of Colombia (UN, Colombia) and at the University of the West of England (UWE, United Kingdom). She has presented many papers at national and international conferences, also organising scientific events. She has also published several articles in national and international magazines. Moreover, she has worked in several film festivals in Italy and Argentina as a programmer and curator. 